\title{
Examining the Effect of Teachers' Perception of Psychological Empowerment on the Stress Level They Perceive
}

\author{
Önder Şanlı \\ Correspondence: Önder Şanlı, Adıyaman Üniversity, Turkey. \\ Received: May 22, 2019 \\ doi:10.11114/jets.v7i8.4283 \\ Online Published: July 26, 2019 \\ URL: https://doi.org/10.11114/jets.v7i8.4283
}

\begin{abstract}
The aim of this study is to find out if there is a correlation and what kind of a correlation there is between how primary, secondary, and high school teachers perceive psychological empowerment provided for them and their perception of stress. The data for this study are based on the opinions of 680 teachers who wereselected by random sampling among the teachers lecturing in the city of Malatya, Turkey,during the 2017-2018 school year. The "Psychological Empowerment Scale" which was developed by Spreitzer (1995) and adapted into Turkish by Gümüşlüoğlu \& Karakitapoğlu (2009), and the "Perceived Stress Scale" which was developed by Cohen, Kamarck \& Mermelstein (1983), and adapted into Turkish by Eskin \& Harlak, Demirkıran \& Dereboy (2013) have been employed as data collection tools.

After analyzing the data obtained during the study, it has been revealed that the average of all the dimensions on the perceived stress scale corresponds to the 'moderate' level, or 'sometimes', while the average of all the dimensions on the psychological empowerment scale corresponds to the high level, or 'very often'. It has been found that there is a significant correlation between the 'gender' variable and the 'self-determination' dimension. Another significant correlation has been observed between 'seniority' variable and 'competence' dimension and psychological empowerment 'in general'. In additionto evaluating the values of the dimension of 'self-determination' on the empowerment scale based on the 'gender' variable, it has been found that the average of male teachers' perception is higher than of female teachers'. Finally, it has been concluded that the teachers' perception of 'impact' significantly predicts their perception of 'insufficient competence'.
\end{abstract}

Keywords: psychological empowerment, stress, teachers

\section{Introduction}

\subsection{Psychological Empowerment}

It can be claimed that psychological empowerment practices have a long history reference.The term employee empowerment was coined based on the opinions held by relationship theorists around the mid-twentieth century (Emet, 2006). In the experiments known as Hawthorne studies and carried out by Elten Mayo, it was claimed that allowing employees to participate in decision making process would do better in terms of financial and emotional benefits (Seçgin, 2007). Those studies overlap the fundamentals of employee empowerment. It can be seen in those studies that there is an emphasis on such ideas of the organizational empowerment as being people-oriented, encouraging teamwork, focusing on productivity both on individual and organizational levels (Hacımustafaoğlu, 2008).

The idea of psychological empowerment of employees has been adopted by those managers who, inthe 1990s, faced with the problem of how a control mechanism which applied to the structures of organizations could be developed, as there was a need for novelty and flexibility at that time (Özbek, 2008 \& Sönmez, 2007). The idea of psychological empowerment of employees, or employee empowerment, is of high significance in today's business world in that it allows codetermination, and increases job satisfaction, as well as decreasing the speed of labor turnover (Hacımustafaoğlu, 2008). Organizational empowerment facilitates cooperation, collaboration, and also codetermination, which is basically a process where employees participate in decision-making, and the extent of which is determined based on mutual trust. It requires executives to lead the way for their staff. It also prioritizes motivating employees, raising their awareness, and helping them (Özgen \& Türk, 1997). Ripley (1992), defines employee empowerment in three different categories: as a term, as a philosophy, and as a type of organizational behavior and program.To assist the reader our study used the following terms and definitions associated with employee empowerment: 
Employee empowerment as a Term: Authorizing employees for certain administrative actions.

Employee empowerment as a Philosophy: Letting employees reach individual and organizational goals in accordance with the visions of an organization.

Employee empowerment as a Type of Organizational Behavior and Program:Banding employees together, and enabling them to know more and develop their skills in order to have a successful organization with successful individuals.

There are various definitions of the term psychological empowerment when it is evaluated considering organizational relationship and motivation issues (Şenel, 2006). Empowerment as a type of relationship means entrustment, a process whereby managers renounce from some of their power in favor of the staff who isrelatively inferior to them (Kanungo, 1992). Considering the above mentionedmotivation issue, empowerment can be defined as a psychological investment in reinforcing the affiliation and positive emotions that employees have of the job and workplace (Şenel, 2006; Çavuş, 2006 \& Zencir, 2004).Psychological empowerment comprises any kind of practice which allows employees to do what they find suitable and important for the aims of an organization, and to do what they feel motivated doing (Çalışkan, 2006). Looking at the definitions of employee empowerment it can be seen that fundamentals of empowerment include letting employees participate inthe decision-making process, delegating to employees, and ensuring that the staff is trying to improve themselves. In this respect,it is possible to claim that the term psychological empowerment is quitedifferent from the task-oriented approaches.

In order to make a comprehensive definition of the term psychological empowerment it can be said that it is a process of preparing an environment in which employees feel confident and competent in terms of their responsibilities and personalities (encouragement), in which they think they can intellectually contribute to the organization in reaching its goals (codetermination, decision-making, problem solving), in which they consider themselves as the real doer (encouraging them to take ownership of their work), in which they feel proud of what they are doing in their off days, and in which they can constantly improve themselves in their work (education) (Şimşek, 2006). It can be said that the empowerment process will leadtosuccess when executives create a setting where there are information sharing, effective communication, a feeling of mutual trust, and effective feedbacks, as well as supporting the staff with education (Koç, 2008). Empowered employees would decide to put their ideas,throughwhich they believe they can do better, into practice. They become naturally liable for the consequences of the decisions made, as they are entitled to access information and sources to make those decisions (Arda, 2008).

The required things to do in a successful organization are as follows (Koçel, 2003)

- Establishing aelliptic structure should be favored. Steep or pyramid-like structures should be avoided, and the use of ranks should be minimised. In other words, removing hierarchy should be the target.

- There should be a participatory atmosphere to activate the workers' ability to address both their own and the company's problems, and to let them demonstrate their skills in developing things.

- The mission and vision statements of the company, and the job descriptions and requirements in the company should be clearly specified and shared with the staff.

- There should be multidirectional communication, so that the flow of information is ensured.

- In order to have effective empowerment, employees should be rendered competent. Necessary educational activities should be planned and carried out to achieve this goal.

Organisational empowerment can hardly work when it is planned only by top management, and when the employees' expectations and ideas are not considered. There should be a negotiation between the parties, and the infrastructure which the staff will need should be constructed.

The qualities that ofthe staff to be empowered should have are as follows (Koçel, 2003):

- Being aware of his or her responsibilities for achieving the goals of the business.

- Being aware of his or her strengths and weaknesses.

- $\quad$ Being in need of and willing to be empowered.

- Having a tendency to learn and improve.

- Having the ability to communicate with the management and his or her environment.

- Being self-confident and having a dynamic personality.

- Openness to diversity, creativity, and novelty.

1.2 Stress

Stressis derived from the Latin word "estrictia". In the 17 th century the word would be used to mean trouble, catastrophe, sorrow, etc. In the 18th and 19th centuries, on the other hand, the term underwent a change in meaning, and would be used to mean difficulty or pressure, and objects, humans, organs or psychological state used to be referred by the term (Pehlivan, 2002). 
Stress implies an interaction between stress stimulus and response. The word stress, then, signifies the interaction between a person and his or her environment, in which the person experiences hardship and challenge which results in damaging his or her well-being, decreasing his or her power (Akbağ, 2000; Ünal \& Ümmet, 2005).

Some researchers point out the peripheral aspects of stress, especially in occupational life, and nearby social groups (Swick, 1987). The main impacts of stress on the life of an individual are as follows:

- Damage in psychological state which is associated with chronic depression and extreme irritability,

- Developing a feeling of despair and inferiority,

- An observable decline in physical and psychological energy,

- Psychosomatic diseases resulting from facing facts.

Individual differences in perceptions of stress and reactions towards stress result in intensity and diversity of physical symptoms. Some of the common symptoms of stress in individuals are feeling constantly tired, insomnia, frequent headaches, idiopathic weight loss, stomach disorders, and sometimes eruption on the skin, which are relatively less affected. However, such serious disorders as high blood pressure, cardiovascular disorders, ulcer, dyspnea or shortness of breath, and abdominal injuries are likely to occur, and these disorders can necessitate urgent and long-term medical treatment (Cardinell, $1980 \&$ Maples, 1980).

Teacher stress can be defined as a teachers' experience of unpleasant, negative emotions resulting from some aspects of their work. (Kyriacou, 2001). According to Veldhoven (1996); teacher stress consists of two components: (1) stress causes and (2) stress responses. Stress causes are the collection of aspects of the work content and the work situation influencing employees at cognitive, motivational and emotional levels. Stress responses are the employees' mental interpretations when experiencing stress causes. The stress level in teachers are most likely to reach the top during interpersonal relationships. These relationships include interactions with principals, colleagues, and students (Gupta, 1981). Another finding has clearly revealed that role ambiguity, poor relations with boss, work overload are the main sources of stress among teachers (Manabete, John, Makinde \& Duwa, 2016). The first step towards tackling stress is to acknowledge its existence. So there is a need to provide proper conducive environment and support to teachers to maintain individual stress at their workplace. Teachers may alter the way to things in optimistic manner which will facilitate them in improving their functional skills and reduce stress. This will ultimately help for higher satisfaction from the profession. (Parrav et al., 2016)

A headmaster, or principal, is a critical stress factor in teachers. The following are the situations that are considered to be most probably leading to stress and teachers' feeling of being hindered:

1- Principals do not support and back the teacher.

2- Principals frequently criticize the teacher.

3- Principals behave towards the teacher in a too formal way.

4- Principals are interested only in how the teacher is doing at work and do not deal with his or her socio-emotional needs (Gupta, 1981).

The educational programs addressing theprofessional development of teachers are only one corner of the polygon of solutions inreducing or relieving the stress. The following list contains the suggestions put forward by Kossack \& Woods (1980) and Wendt (1980).

1- Maintaining a good physical and emotional state through a balanced diet, exercising regularly, and taking up new hobbies and areas of interest.

2- Avoiding those colleagues who constantly complain about the educational programs.

3- Establishing personal and professional relationships in which there is interaction through effective brainstorming.

4- Learning how to be more sensitive and honest when interacting with students, parents, colleagues, and principals.

5- Learning how to be frank and intimate in discussions, and being eager to convey the conversation to positive ends.

6- Participating in interesting professional activities, projects, and research studies

7- Joining, or enrolling, in organisations which appeal to you, and are relevant to your job. Such organisations can support their members in understanding their basic problems.

Healthy teachers positively affect others with whom the teachers interact. The biggest effect would probably be on students. The health of teachers could be seriously affected by stress (Wiley, 2000). Moreover, apart from teachers themselves, work stress suffered by them can also adversely affect their students and the learning environment (Chan \& Hui, 1995). The students would feel discomfort, when their teachers are down hearted. At schools as educational organisations, there are 
many things that can negatively affect the psychology of the students. Unless those negative effects are eliminated, psychological problems and stress in students will be inevitable. In societies, which are in a rapid process of change, and consequently getting complicated day by day, it becomes very difficult to raise the youth in a way that is appropriate for their future lives, and the instructional part of education falls short of meeting this demand (Kılıçç1, 2000). Considering only this fact, it becomes really important for teachers to do their job of education in a less stressful environment.

\subsection{The Aim of the Study}

The aim of this study is to determine what kind of a correlation there is, if any, between primary, secondary, and high school teachers' perception of psychological empowerment and their perception of stress. The correlation between how teachers perceive psychological empowerment and the variables of age, gender, seniority, subject matter, the time of working at the same school, and school type are established based on the following questions:

1- What are the levels of teachers' perception of psychological empowerment and of the stress scale?

2- Does teachers' perception of psychological empowerment vary according to marital status, gender, school type, subject matter, time of service at school, and age variables?

3- Is there a significant correlation between teachers' perception of psychological empowerment and ef-stress scale?

4- Given that teachers' perception of 'impact' predicts their perception of 'insufficient competence', can someone claim that the variables of age, seniority, gender, and marital status also predict a significant relationship?

\section{Method}

\subsection{Study Group}

The study group consists of 680 teachers selected by random sampling method among those who lecture on different subject matters in state schools in Malatya, Turkey, in the 2017 - 2018 school year. These state schools include primary, secondary, and high schools. Probability or random sampling means that every item in the population has an equal chance of being included in sample. One way to undertake random sampling would be if researcher was to construct a sampling frame first and then used a random number generation computer program to pick a sample from the sampling frame (Zikmund, 2002). Probability or random sampling has the greatest freedom from bias but may represent the most costly sample in terms of time and energy for a given level of sampling error (Brown, 1947).

The other defining information about the teachers who participated in this study is presented in Table 1.

Table 1. Demographic information about the teachers who have participated in this research

\begin{tabular}{|c|c|c|c|}
\hline Variables & Categories & $\mathbf{N}$ & $\%$ \\
\hline & Male & 397 & 58.4 \\
\hline \multirow{3}{*}{ Gender } & Female & 283 & 41.6 \\
\hline & Total & 680 & 100.0 \\
\hline & Married & 546 & 80.3 \\
\hline \multirow{4}{*}{ Marital Status } & Single & 134 & 19.7 \\
\hline & Total & 680 & 100.0 \\
\hline & $20-30$ years old & 142 & 20.9 \\
\hline & $31-40$ years old & 303 & 44.6 \\
\hline \multirow{6}{*}{ Age } & 41 - 50 years old & 187 & 27.5 \\
\hline & 51 - 60 years old & 46 & 6.8 \\
\hline & Over 61 years old & 2 & .3 \\
\hline & Total & 680 & 100.0 \\
\hline & $1-10$ years & 264 & 38.8 \\
\hline & $11-20$ years & 284 & 41.8 \\
\hline \multirow[t]{5}{*}{ Years of teaching } & 21 - 30 years & 115 & 16.9 \\
\hline & +31 years & 17 & 2.5 \\
\hline & Total & 680 & 100.0 \\
\hline & $1-5$ years & 487 & 71.6 \\
\hline & $6-10$ years & 134 & 19.7 \\
\hline \multirow{4}{*}{$\begin{array}{l}\text { Time of Service at the } \\
\text { Same School }\end{array}$} & 11- 15 years & 36 & 5.3 \\
\hline & $16-20$ years & 14 & 2.1 \\
\hline & +21 years & 9 & 1.3 \\
\hline & Total & 680 & 100.0 \\
\hline \multirow{3}{*}{ Subject Matter } & Primary & 142 & 20.9 \\
\hline & $\begin{array}{l}\text { 1 eacher } \\
\text { Other Fields }\end{array}$ & 538 & 79.1 \\
\hline & Total & 680 & 100.0 \\
\hline \multirow{4}{*}{ School Type } & Primary School & 163 & 24.0 \\
\hline & Secondary School & 190 & 27.9 \\
\hline & High School & 327 & 48.1 \\
\hline & Total & 680 & 100.0 \\
\hline
\end{tabular}


Gender variable showed that the number of male teachers is 397 , and the number of female teachers is 283 which correspond to the percentages of $58.4 \%$ and $41.6 \%$ respectively. But in Turkey about $55 \%$ of teachers are and female $45 \%$ teachers are male. Marital status variable indicates that 546 of the teachers are married, while 134 of them are single, which equal to $80.3 \%$ and $19.7 \%$ respectively. Anage variable suggests that $142(20.9 \%)$ of the teachers are at the age $20-30,303(44.6 \%)$ of them are at the age 31-40, 187 (27.5\%) of them 41-50 years old, $46(6.8 \%)$ of them 51-60, and 2 $(0.3 \%)$ of them are over 61 years old. Seniority variable implies that $264(38.8 \%)$ of them have been working for 1-10 years, $284(41.8 \%)$ of them for 11-20 years, $115(16.9 \%)$ of them in21-30years, and the remaining $17(2.5 \%)$ of them have been working for more than 31 years. The time of service at the same school variable shows that $487(71.6 \%)$ of them have been lecturing at the same school for 1-5 years, 134 (19.7\%) of them for 6-10 years, $36(5.3 \%)$ of them for $11-15$ years, $14(2.1 \%)$ of them for 16-20 years, and $9(1.3 \%)$ of them have been lecturing at the same school for more than 21 years. Subject matter variable indicates that $142(20.9 \%)$ of the teachers studied are primary school teachers, while the remaining $538(79.1 \%)$ of them have their areas of expertise. Finally, school type variable shows that 163 (24\%) of the teachers studied are primary school teachers, $190(27.9 \%)$ of them are secondary, and $327(48.1 \%)$ of them are high school teachers.

\subsection{Data Collection Tools}

Information Gathering Form: The form has been developed by the researchers in this study to collect the demographic information about the teachers who participated in the study. It was in Turkish and includes questions about age, gender, time of total service, or seniority, marital status, time of service at the same school, and school type.

Psychological Empowerment Scale: The scale was developed by Spreitzer in 1995. It was designed in four dimensions, namely meaning, competence, self-determination, and impact, and it includes 12 questions. The statements made by teachers are classified under the five-point Likert-type Scale in which the number 1 corresponds to 'Strongly Disagree', while the number 5 corresponds to 'Strongly Agree'. The reliability of the questions in the question form of the scale has was determined by Cronbach's Alpha, which measured 0.895. This is an appropriate value for the internal consistency of the scale.

Perceived Stress Scale (PSS): The scale was developed by Cohen, Kamarck, and Mermelstein (1983), and adapted into Turkish by Eskin, Harlak, Demirkıran, and Dereboy (2013). The Perceived Stress Scale which consists of 14 items was designed to measure how stressful some situations in an individual's life are. The participants chose the best option among the ones ranging from 0 (never) to 4 (very often) on a five-point Likert-type scale. The reliability of the questions in the question form of the scale had been determined by Cronbach's Alpha, which measured 0.84 . This value is statistically a reliable value. (Lin, Liang, \& Tsai, 2015) points on the Likert-type scale are presented in Table 2.

Table 2. The criteria of the evaluation of the items in the questionnaire

\begin{tabular}{llll}
\hline Value & Option & Range & Level \\
\hline $\mathbf{1}$ & Never & $1.00-1.80$ & Very Low \\
$\mathbf{2}$ & Rarely & $1.81-2.60$ & Below Average \\
$\mathbf{3}$ & Sometimes & $2.61-3.40$ & Average \\
$\mathbf{4}$ & Very Often & $3.41-4.20$ & Above Average \\
$\mathbf{5}$ & Always & $4.21-5.00$ & Very High \\
\hline
\end{tabular}

The scale used is based on the Likert-type five-point scale. When the differential, which is $5-1=4$, is divided by the standard judgment, which is 5 , a value of 0.80 is obtained, which determines the range in between the values. The dimensions of the Psychological Empowerment Scale in Table 4, and of the Perceived Stress Scale in Table 5 will be interpreted in accordance with the criteria presented in Table 2.

Pearson's Correlation Coefficient is used to determine the correlation between variables. The correlations between scales are assessed based on the following criteria (Kalayc1, 2006).

Table 3. The level of correlation between variables

\begin{tabular}{ll}
\hline $\mathbf{r}$ & Level of Correlation \\
\hline $0.00-0.25$ & Very Low \\
\hline $0.26-0.49$ & Low \\
\hline $0.50-0.69$ & Moderate \\
\hline $0.70-0.89$ & High \\
\hline $0.90-1.00$ & Very High \\
\hline
\end{tabular}


The findings have been interpreted based on $95 \%$ confidence interval and 5\% significance level. Before moving on to analyses, the data were purified from Type I and Type II errors, reverse scoring, and extreme values.

\subsection{Data Analysis Techniques Used in the Research}

As for statistically analysing the data, SPSS 22.0 package software was used for descriptive analysis, t-test was used for independent variables, in addition to one-way analysis of variance (ANOVA), Pearson's Product-Moment Correlation Coefficient, and Multiple Linear Regression Analysis.

\section{Findings}

This section shows the findings obtained from analysis of the data obtained through scales which are used to answer the research problem of this study. Explanations and interpretations have been made based on the findings obtained.

The values from the analysis of the answers to the question of "What are the levels of teachers' perception of the dimensions of psychological empowerment and of stress scale?" have been presented in Tables 4 and 5.

Table 4. The values of the dimensions of psychological empowerment scale

\begin{tabular}{llll}
\hline Variable & $\mathbf{X}$ & Standard Error & Standard Derivation \\
\hline Meaning & 4.1423 & .02667 & .69546 \\
Competence & 3.9865 & .02679 & .69862 \\
Self-determination & 3.7964 & .02704 & .70521 \\
Impact & 3.9579 & .02598 & .67749 \\
Psychological empowerment (in general) & 3.9708 & .02330 & .60755
\end{tabular}

Table 4 indicates that the averages of the dimensions of the psychological empowerment scale range from 3.41 to 4.20 (Very often). In this regard, it can be said that the level of participants' perception of empowerment is 'above average'.

Table 5. The values of the dimensions of perceived stress scale

\begin{tabular}{llll}
\hline Variables & $\mathbf{X}$ & Standard Error & Standard Derivation \\
\hline Perception of Insufficient Competence & 3.1542 & .01102 & .28726 \\
Perception of Stress/Disorder & 2.9188 & .00957 & .24943 \\
Stress (in general) & 3.0365 & .00676 & .17638 \\
\hline
\end{tabular}

Table 5 implies that the averages of the dimensions of the stress scale range from 2.61 to 3.40 (Sometimes). In this respect, it can be said that the level of participants' passion for work is 'average'. Results of the analysis of the answers to the question of "Does teachers' perception of psychological empowerment vary according to marital status, gender, school type, subject matter, time of service at school, and age variables?" show that there is no significant variation between the dimensions of empowerment scale and the variables marital status $(\mathrm{p}=0.248>0.05)$, subject matter $(\mathrm{p}=0.68>0.05)$, school type $(\mathrm{p}=0.418>0.05)$, time of service at the same school $(\mathrm{p}=0.70>0.05)$, and age $(\mathrm{p}=0.66>0.05)$.

However, the same results demonstrate a significant correlation between the gender variable and the dimension of 'self-determination' ( $\mathrm{p}=0.006<0.05)$; between the seniority variable and the dimensions of 'meaning' $(\mathrm{p}=0.002<0.05)$, 'competence' $(p=0.013<0.05)$ and 'in general' $(p=0.021<0.05)$ on the empowerment scale. The findings of these correlations are presented in Tables 6, 7, and 8.

Table 6. The comparison of the values of the dimension 'self-determination' on the psychological empowerment scale and of the variable 'gender'

\begin{tabular}{llcccccc}
\hline Gender & $\mathbf{N}$ & $\overline{\mathbf{X}}$ & Standard Derivation & Self-determination & $\mathbf{T}$ & $\mathbf{p}$ \\
\hline Male & 397 & 3.8593 & .70363 & 678 & 2.772 & $0.006^{* *}$ \\
Female & 283 & 3.7080 & .69914 & & & \\
Total & 680 & & & & & & \\
$* \mathrm{p}<0.05 * * \mathrm{p}<0.01 * * * \mathrm{p}<0.001$ & & & & & & & \\
\hline
\end{tabular}

Looking at the values of the dimension of 'self-determination' in Table 6, it can be seen that the average of male teachers' perception is higher than of female teachers'. The questions in the dimension of 'self-determination' are about to what extent employees make decisions about activities in a workplace, and the answers in this study suggest that 
male teachers have more freedom of making decisions about what is to be done at schools than female teachers.

Table 7. The values of the psychological empowerment scale with respect to meaning, competence, and psychological empowerment in general

\begin{tabular}{|c|c|c|c|}
\hline Meaning & $\mathbf{N}$ & $\overline{\bar{X}}$ & St. Der. \\
\hline $1-10$ years & 264 & 4.1479 & .67464 \\
\hline $11-20$ years & 284 & 4.0602 & .75004 \\
\hline 21 - 30 years & 115 & 4.3552 & .52456 \\
\hline More than 31 years & 17 & 3.9847 & .81289 \\
\hline Total & 680 & 4.1423 & .69546 \\
\hline Competence & $\mathrm{N}$ & $\bar{X}$ & St. Der. \\
\hline $1-10$ years & 264 & 3.9842 & .68421 \\
\hline 11 - 20 years & 284 & 3.9273 & .73941 \\
\hline 21 - 30 years & 115 & 4.1798 & .56760 \\
\hline More than 31 years & 17 & 3.7059 & .79828 \\
\hline Total & 680 & 3.9865 & .69862 \\
\hline Psychological empowerment (in general) & $\mathrm{N}$ & $\overline{\boldsymbol{X}}$ & St. Der. \\
\hline $1-10$ years & 264 & 3.9649 & .58968 \\
\hline $11-20$ years & 284 & 3.9181 & .66267 \\
\hline 21 - 30 years & 115 & 4.1274 & .47179 \\
\hline More than 31 years & 17 & 3.8827 & .60122 \\
\hline Total & 680 & 3.9708 & .60755 \\
\hline
\end{tabular}

Table 8. The One Way Analysis of Variance (ANOVA) results of the values of the dimensions 'meaning', 'competence', and 'psychological empowerment in general' on the empowerment scale with respect to the 'seniority' variable

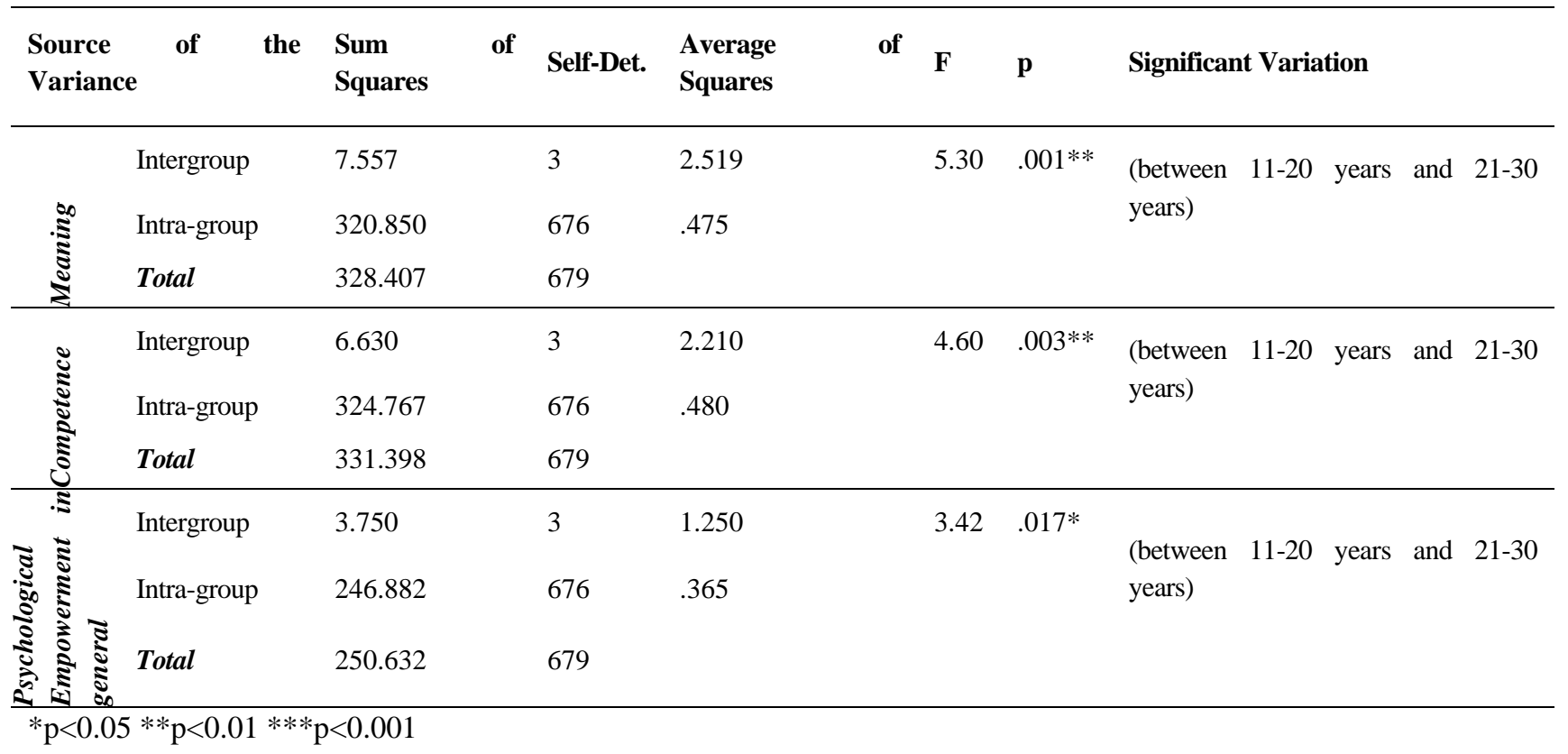

Table 8 shows that there is a significant variation in 'meaning' dimension between 11-20 years $\left(\bar{X}_{11-20 \mathrm{yrs}}=4.0602\right)$ and 21-30 years of seniority $\left(\bar{X}_{21-30 \mathrm{yrs}}=4.3552\right)$ based on the one way analysis of variance and post-hocScheffe test $\left(\mathrm{F}_{(3-679)}=5.307, \mathrm{p}<0.01\right)$. Looking at the average values of the groups, it can be seen that the values of teachers' perception of 'meaning' are significantly high. There is a significant correlation between the teachers of 11-20 years of seniority and the teachers of 21-30 years of seniority. It can be inferred that the latter group of teachers' perception of 'meaning' is higher than the former group. 
As for the dimension of 'competence', it has been found that there is a significant correlation between the teachers of 11-20 years of seniority $\left(\bar{X}_{11-20 \mathrm{yrs}}=3.9273\right)$ and the teachers of $21-30$ years of seniority $\left(\bar{X}_{21-30 \mathrm{yrs}}=4.1798\right)\left(\mathrm{F}_{(3-679)}=4.600\right.$, $\mathrm{p}<0.01)$. Those who have 21-30 years of seniority have been found to have a higher level of 'competence'.

Finally, regarding the dimension of 'in general' on the empowerment scale, it has been found that there is a significant correlation between the teachers of 11-20 years of seniority $\left(\bar{X}_{11-20 \mathrm{yrs}}=3.9181\right)$ and the teachers of 21-30 years of seniority $\left(\bar{X}_{21-30 \text { yrs }}=4.1274\right)\left(\mathrm{F}_{(3-679)}=3.423, \mathrm{p}<0.01\right)$. Those who have 21-30 years of seniority have been found to have a higher level of the dimension 'in general' on the empowerment scale.

All in all, it can be inferred that the teachers of 21-30 years of seniority have higher levels of the dimensions of 'meaning', of 'competence', and of 'in general' on the psychological empowerment scale than the teachers in the other groups of seniority. It can be deduced that the teachers of 21-30 years of seniority find the activities related to their job more meaningful, that they are more confident of their own abilities, that they feel more independent in doing things about their job, that they take more care about their job, and that they feel stronger, in general.

Table 9. The correlation table of the dimensions of psychological empowerment (ee) and passion for work scales

\begin{tabular}{|c|c|c|c|c|c|c|c|c|}
\hline & $\begin{array}{l}\text { Ee. } \\
\text { Meanin } \\
\text { g }\end{array}$ & $\begin{array}{l}\text { Ee. } \\
\text { Competenc } \\
\text { e }\end{array}$ & $\begin{array}{l}\text { Ee. } \\
\text { Self-Determinatio } \\
n\end{array}$ & $\begin{array}{l}\text { Ee. } \\
\text { Impac } \\
\text { t }\end{array}$ & $\begin{array}{l}\text { Ee.In } \\
\text { Genera } \\
\text { l }\end{array}$ & $\begin{array}{l}\text { Stress } \\
\text { Insufficient } \\
\text { Competenc } \\
\text { e } \\
\end{array}$ & $\begin{array}{l}\text { Stress } \\
\text { Disorde } \\
\mathbf{r}\end{array}$ & $\begin{array}{l}\text { Stress } \\
\text { In } \\
\text { Genera } \\
\text { l } \\
\end{array}$ \\
\hline Ee.Meaning & 1 & & & & & & & \\
\hline Ee.Competence & $.753^{* * * *}$ & 1 & & & & & & \\
\hline $\begin{array}{l}\text { Ee.Self-determinatio } \\
\text { n }\end{array}$ & $.591^{* * *}$ & $.688^{* * * *}$ & 1 & & & & & \\
\hline Ee.Impact & $.644^{* * *}$ & $.754^{* * *}$ & $.699^{* * *}$ & 1 & & & & \\
\hline Ee.In general & $.854^{* * * * *}$ & $.913^{* * * *}$ & $.852^{* * * *}$ & $.883^{* * * *}$ & 1 & & & \\
\hline $\begin{array}{l}\text { S.Insufficient } \\
\text { Competence }\end{array}$ & $.207^{* * *}$ & $.184^{* * *}$ & $.104^{* *}$ & $.176^{* * *}$ & $.192^{* *}$ & 1 & & \\
\hline $\begin{array}{l}\text { S. Disorder } \\
\text { Stress In general }\end{array}$ & $\begin{array}{l}-.126^{* * * *} \\
.080^{*}\end{array}$ & $\begin{array}{l}-.088^{*} \\
.088^{*}\end{array}$ & $\begin{array}{l}-.068^{*} \\
.037^{* *}\end{array}$ & $\begin{array}{l}-.121^{* *} \\
.058^{*}\end{array}$ & $\begin{array}{l}-.115^{* * *} \\
.075^{*}\end{array}$ & $\begin{array}{l}-.142^{* * * *} \\
.714^{* * *}\end{array}$ & $\begin{array}{l}1 \\
.592^{* * *}\end{array}$ & 1 \\
\hline
\end{tabular}

$* \mathrm{p}<0.05 * * \mathrm{p}<0.01 * * * \mathrm{p}<0.001$

The results of the correlation analysis, as are shown in Table 9, suggest that there is a positive correlation between the 'meaning' dimension on the psychological empowerment scale and all the other dimensions on the same scale. This positive relationship also applies to all of the dimensions on the stress scale, except for the 'disorder' dimension, which has a negative relationship with the other dimensions. There is a 'high' level of correlation between the dimensions of 'meaning' and 'competence' ( $\left.\mathrm{r}=0.753 ; \mathrm{r}^{2}=0.567\right) .56 \%$ of the 'meaning' behaviors can be explained by the 'competence' behaviors. There is a 'moderate' level of correlation between the behaviors of 'meaning' and 'self-determination' $\left(\mathrm{r}=0.591 ; \mathrm{r}^{2}=0.349\right) .34 .9 \%$ of the 'meaning' behaviors can be explained by the 'self-determination' behaviors. There is a 'moderate' level of correlation between the behaviors of 'meaning' and 'impact' $\left(\mathrm{r}=0.644 ; \mathrm{r}^{2}=0.414\right) .41 .4 \%$ of the 'meaning' behaviors can be explained by the 'impact' behaviors. There is a 'high' level of correlation between the behavior of 'meaning' and empowerment 'in general' ( $\left.\mathrm{r}=0.854 ; \mathrm{r}^{2}=0.729\right) .72 .9 \%$ of the 'meaning' behaviors can be explained by the empowerment 'in general'. There is a 'very low' level of correlation between the behavior of 'meaning' and the dimension of 'insufficient competence' $\left(\mathrm{r}=0.207 ; \mathrm{r}^{2}=0.042\right)$. Only $4.2 \%$ of the 'meaning' behaviors can be explained by the 'insufficient competence' behaviors. There is a 'very low' level of correlation between the behavior of 'meaning' and perceived stress 'in general' $\left(r=0.080 ; r^{2}=0.006\right)$.

There is a positive relationship between the 'competence' dimension on the psychological empowerment scale and all the other dimensions on the same scale. This positive relationship also applies to all of the dimensions on the stress scale, except for the 'disorder' dimension, which has a negative relationship with the other dimensions. There is a 'moderate' level of correlation between the behaviors of 'competence' and 'self-determination' $\left(r=0.688 ; r^{2}=0.473\right)$. $47.3 \%$ of the 'competence' behaviors can be explained by the 'self-determination' behaviors. There is a 'high' level of correlation between the behaviors of 'competence' and 'impact' $\left(\mathrm{r}=0.754 ; \mathrm{r}^{2}=0.568\right) .56 .8 \%$ of the 'competence' behaviors can be explained by the 'impact' behaviors. There is a 'very high' level of correlation between the behavior of 'competence' and the psychological empowerment 'in general' $\left(\mathrm{r}=0.913 ; \mathrm{r}^{2}=0.833\right) .83 .3 \%$ of the 'competence' behaviors can be explained by the psychological empowerment 'in general'. There is a 'very low' level of correlation between the behavior of 'competence' and the dimension of 'insufficient competence' on the stress scale ( $\mathrm{r}=0.184$; $\mathrm{r}^{2}=0.033$ ). Only $3.3 \%$ of the 'competence' behavior can be explained by the 'insufficient competence' behaviors. There is a 'very low' level relationship between the behavior of 'competence' and the stress 'in general' on the perceived stress scale $\left(\mathrm{r}=0.088 ; \mathrm{r}^{2}=0.007\right)$.

There is a positive correlation between the 'self-determination' dimension on the psychological empowerment scale and 
all the other dimensions on the same scale. This positive relationship also applies to all of the dimensions on the stress scale, except for the 'disorder' dimension, which has a negative relationship with the other dimensions. There is a 'moderate' level of correlation between the behaviors of 'self-determination' and 'impact' ( $\left.\mathrm{r}=0.699 ; \mathrm{r}^{2}=0.488\right)$. 48.8\% of the 'self-determination' behaviors can be explained by the 'impact' behaviors. There is a 'high' level of correlation between the behavior of 'self-determination' and the empowerment scale 'in general' $\left(\mathrm{r}=0.852 ; \mathrm{r}^{2}=0.725\right) .72 .5 \%$ of the 'self-determination' behaviors can be explained by the empowerment scale 'in general'. There is a 'very low' level of correlation between the behavior of 'self-determination' and the dimension of 'insufficient competence' on the stress scale $\left(\mathrm{r}=0.104 ; \mathrm{r}^{2}=0.010\right)$. Only $1 \%$ of the 'competence' behaviors can be explained by the 'insufficient competence' behaviors. There is a 'very low' level of correlation between the behavior of 'self-determination' and the stress 'in general' on the perceived stress scale $\left(\mathrm{r}=0.037 ; \mathrm{r}^{2}=0.001\right)$.

There is a 'high' level of correlation between the behavior of 'impact' and the empowerment scale 'in general' ( $\mathrm{r}=0.883$; $\left.\mathrm{r}^{2}=0.779\right) .77 .9 \%$ of the 'impact' behaviors can be explained by the empowerment scale 'in general'. There is a 'very low' level of correlation between the behavior of 'impact' and the dimension of 'insufficient competence' on the perceived stress scale $\left(\mathrm{r}=0.176 ; \mathrm{r}^{2}=0.030\right)$. Only $3 \%$ of the 'impact' behaviors can be explained by the 'insufficient competence' behaviors. There is a 'very low' level of correlation between the behavior of 'impact' and the stress 'in general' on the perceived stress scale $\left(\mathrm{r}=0.058 ; \mathrm{r}^{2}=0.003\right)$.

There is a 'very low' level of correlation between the behavior of 'in general' on the psychological empowerment scale and the dimension of 'insufficient competence' on the stress scale $\left(\mathrm{r}=0.192 ; \mathrm{r}^{2}=0.036\right)$. Only $3.6 \%$ of the behaviors of 'in general' on the empowerment scale can be explained by the 'insufficient competence' behavior. There is a 'very low' level of correlation between the behavior of 'in general' on the empowerment scale and the behavior of 'in general' on the perceived stress scale $\left(r=0.075 ; r^{2}=0.005\right)$.

There is a 'high' level of correlation between the behavior of 'insufficient competence' on the stress scale and the behavior of 'in general' on the same scale $\left(r=0.714 ; \mathrm{r}^{2}=0.509\right) .50 .9 \%$ of the behaviors of 'insufficient competence' on the stress scale can be explained by the behavior of 'in general' on the same scale.

Finally, there is a 'moderate' level of correlation between the behavior of 'disorder' and the behavior of 'in general' on the perceived stress scale $\left(\mathrm{r}=0.592 ; \mathrm{r}^{2}=0.350\right) .35 \%$ of the behaviors of 'disorder' can be explained by the behavior of 'in general' on the perceived stress scale.

The values extracted from multiple linear regression analysis of the answers given to the question of "Given that teachers' perception of 'impact' predicts their perception of 'insufficient competence', can someone claim that the variables of age, seniority, gender, and marital status also predict a significant relationship?" are presented in Table 10.

Table 10. The results of multiple regression analysis of the gender, age, seniority, and marital status variables

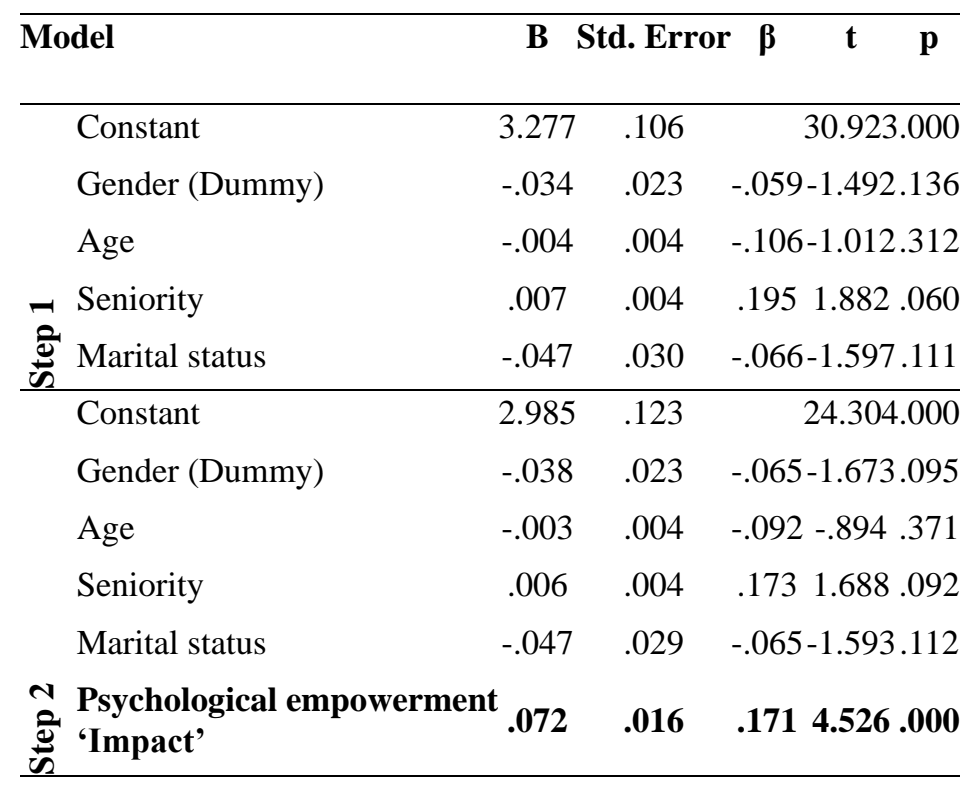

Dependent Variable: Insufficient Competence

$\Delta \mathrm{R}^{2}=0.049 * * *(* \mathrm{p}<0.05 * * \mathrm{p}<0.01 * * * \mathrm{p}<0.001)$

Table 10 shows the results of the analysis of the answers given to the question of "Given that teachers' perception of 'impact' predicts their perception of 'insufficient competence', can someone claim that the variables of age, seniority, 
gender, and marital status also predict a significant relationship?". As the table suggests, gender, age, seniority, and marital status variables have been made to control variables in Step 1 to determine the level of correlation between the behaviors of 'impact' and 'insufficient competence'. Then, it has been found in Step 2 that the behavior of 'impact' in teachers significantly predicts the function of the organizational structure $(\beta=0.171 ; \mathrm{p}<0.001)$. This equation tells that one unit of increase in 'impact' behavior causes 0.171 unit of an increase in 'insufficient competence' behavior at an organisational level. As for the variance provided, it can be seen that $4.9 \%$ of 'insufficient competence' behaviors can be explained by 'impact' behavior $\left(\Delta \mathrm{R}^{2}=0.049 ; \mathrm{p}<0.001\right)$.



Figure 1. The effect of teachers' level of 'impact' on their level of 'insufficient competence' $\left({ }^{*} \mathrm{p}<0.05^{* *} \mathrm{p}<0.01{ }^{* * *} \mathrm{p}<0.001\right)$

Examining the participant teachers' answers to the fourth question of 'Given that teachers' perception of 'impact' predicts their perception of 'insufficient competence', can someone claim that the variables of age, seniority, gender, and marital status also predict a significant relationship?", it can be seen that the answer to the question is 'yes' $(\beta=0.171 ; \mathrm{p}<0.001)$.

\section{Results and Discussion}

It is recommended that the human resources at hand be used as reasonably as possible in order to maintain an organizational efficiency (Siegall \& Gardner, 2000). It has been found that employees should be delegated in order for the organisation to be effective and successful. One of the methods of making employees in an organisation participate in the decision-making process is empowering them, since empowerment is a fundamental component of organizational and administrative effectiveness, and it plays a central part in maintaining and developing collective consciousness (Conger \& Kanungo, 1988).

It has been deduced that the averages of the dimension on the psychological empowerment scale are at the level of 'very often'. In this sense, it can be claimed that the participants' perception of the empowerment scale is at a 'high' level. In his work Doğan (2006), concluded that the ones who were appreciated and cared about were more likely to feel stronger.

Also, it has can be seen that the averages of the dimension on the perceived stress scale are at the level of 'sometimes'. In this respect, it can be said that the participants regard their stress level 'moderate'. Aslan (1995), concluded that teachers assumed their job a bit stressful and that they could not do well for that reason. This conclusion supports our findings.

It has been found that there is a significant correlation between the 'gender' variable and the 'self-determination' dimension. Another significant correlation has been observed between the 'seniority' variable and 'competence' dimension and psychological empowerment 'in general'.

Looking at the values of the dimension of 'self-determination' on the empowerment scale, it can be seen that the average of male teachers' perception is higher than female teachers'. The questions in the dimension of 'self-determination' are about to what extent employees make decisions about activities in a workplace, and the answers in this study suggest that male teachers have more freedom of making decisions about what is to be done at schools than female teachers.

Based on the one-way analysis of variance and post-hocScheffe test it can be claimed that in 'meaning' dimension of the empowerment scale, there is a significant variation between 11-20 years and 21-30 years of seniority. Looking at the average values of the groups, it can be seen that the values of the teachers' perception of 'meaning' are significantly high. There is a significant correlation between the teachers having 11-20 years of seniority and the teachers having 21-30 years of seniority. It can be inferred that the latter group of teachers' perception of 'meaning' is higher than the former group.

It has also been found out that there is a significant relationship between the 'competence' dimension and 'seniority' variable. The teachers having 21-30 years of seniority have a higher level of 'competence' than the ones having 11-20 years of seniority. 
This significant correlation applies also to the relationship between 'seniority' and empowerment scale 'in general'. The teachers of 21-30 of seniority have a higher level of perception of 'in general' dimension on the empowerment scale than the ones of 11-20 years of seniority. When the values obtained from the findings are examined in depth, it can be inferred that the teachers of 21-30 years of seniority have higher levels of the dimensions of 'meaning', of 'competence', and of 'in general' on the psychological empowerment scale than the teachers in the other groups of seniority. Furthermore, it can be deduced that the teachers of 21-30 years of seniority find the activities related to their job more meaningful, that they are more confident of their own abilities, that they feel more independent in doing things about their job, that they take more care about their job, and that they feel stronger, in general.

The results of the correlation analysis suggest that there is a positive correlation between the 'meaning' dimension on the psychological empowerment scale and all the other dimensions on the same scale. This positive relationship also applies to all of the dimensions on the stress scale, except for the 'disorder' dimension, which has a negative relationship with the other dimensions. There is a 'high' level of correlation between the dimensions of 'meaning' and 'competence'. $56 \%$ of the 'meaning' behaviors can be explained by the 'competence' behaviors. There is a 'moderate' level of correlation between the behaviors of 'meaning' and 'self-determination'. $34.9 \%$ of the 'meaning' behaviors can be explained by the 'self-determination' behaviors. There is a 'moderate' level of correlation between the behaviors of 'meaning' and 'impact'. $41.4 \%$ of the 'meaning' behaviors can be explained by the 'impact' behaviors. There is a 'high' level of correlation between the behavior of 'meaning' and empowerment 'in general'. $72.9 \%$ of the 'meaning' behaviors can be explained by the empowerment 'in general'. There is a 'very low' level of correlation between the behavior of 'meaning' and the dimension of 'insufficient competence'. Only $4.2 \%$ of the 'meaning' behaviors can be explained by the 'insufficient competence' behaviors. There is a 'very low' level of correlation between the behavior of 'meaning' and perceived stress 'in general'. Only $0.6 \%$ of the 'meaning' behaviors can be explained by the 'in general' behaviors on the perceived stress scale. It is noteworthy that the 'meaning' dimension is mostly influenced by the 'in general' behavior on the empowerment scale by a rate of $72.9 \%$, which is followed by the 'competence' dimension by a rate of 56.7\%. In a research done by Fulford \& Enz (1995),it was discovered that there was a positive relationship between the dimensions of 'satisfaction', 'employee performance', 'loyalty', 'service delivery' and the dimensions of 'meaning', 'competence', 'impact' (Hançer \& Georger, 2003).

There is a positive relationship between the 'competence' dimension on the psychological empowerment scale and all the other dimensions on the same scale. This positive relationship also applies to all of the dimensions on the stress scale, except for the 'disorder' dimension, which has a negative relationship with the other dimensions. There is a 'moderate' level of correlation between the behaviors of 'competence' and 'self-determination'. 47.3\% of the 'competence' behaviors can be explained by the 'self-determination' behaviors. There is a 'high' level of correlation between the behaviors of 'competence' and 'impact'. 56.8\% of the 'competence' behaviors can be explained by the 'impact' behaviors. There is a 'very high' level of correlation between the behavior of 'competence' and the psychological empowerment 'in general'. $83.3 \%$ of the 'competence' behaviors can be explained by the psychological empowerment 'in general'. There is a 'very low' level of correlation between the behavior of 'competence' and the dimension of 'insufficient competence' on the stress scale. Only 3.3\% of the 'competence' behavior can be explained by the 'insufficient competence' behaviors. There is a 'very low' level relationship between the behavior of 'competence' and the stress 'in general' on the perceived stress scale. Only $0.7 \%$ of 'competence' behaviors can be explained by the behavior of 'in general' on the empowerment scale. It becomes remarkable then that the dimension of 'competence' is mostly affected by the 'in general' behavior on the empowerment scale by a rate of $83.3 \%$, which is followed by the 'impact' dimension by a rate of $56.8 \%$.

There is a positive correlation between the 'self-determination' dimension on the psychological empowerment scale and all the other dimensions on the same scale. This positive relationship also applies to all of the dimensions on the stress scale, except for the 'disorder' dimension, which has a negative relationship with the other dimensions. There is a 'moderate' level of correlation between the behaviors of 'self-determination' and 'impact'. $48.8 \%$ of the 'self-determination' behaviors can be explained by the 'impact' behaviors. There is a 'high' level of correlation between the behavior of 'self-determination' and the empowerment scale 'in general'. $72.5 \%$ of the 'self-determination' behaviors can be explained by the empowerment scale 'in general'. There is a 'very low' level of correlation between the behavior of 'self-determination' and the dimension of 'insufficient competence' on the stress scale. Only $1 \%$ of the 'competence' behaviors can be explained by the 'insufficient competence' behaviors. There is a 'very low' level of correlation between the behavior of 'self-determination' and the stress 'in general' on the perceived stress scale. Only $0.1 \%$ of the 'self-determination' behaviors can be explained by the stress 'in general' on the perceived stress scale. It can be claimed then that the 'self-determination' dimension is most highly impacted by the 'in general' behavior on the empowerment scale with a rate of $72.5 \%$, and the second highest impact comes from the 'impact' dimension with a rate of $48.8 \%$. 
There is a 'high' level of correlation between the behavior of 'impact' and the empowerment scale 'in general'. $77.9 \%$ of the 'impact' behaviors can be explained by the empowerment scale 'in general'. There is a 'very low' level of correlation between the behavior of 'impact' and the dimension of 'insufficient competence' on the perceived stress scale. Only $3 \%$ of the 'impact' behaviors can be explained by the 'insufficient competence' behaviors. There is a 'very low' level of correlation between the behavior of 'impact' and the stress 'in general' on the perceived stress scale. Only $0.3 \%$ of the impact behaviors can be explained by the stress 'in general' on the perceived stress scale. These findings show us that the 'impact' dimension is mostly affected by the empowerment scale 'in general' with a rate of $77.9 \%$, and second secondly by 'insufficient competence' with a rate of 3\%. In their research Doğan \& Demiral (2009) found that there was a significant correlation in the dimensions of 'impact' and 'meaning', which supports the findings in this study.

There is a 'very low' level of correlation between the behavior of 'in general' on the psychological empowerment scale and the dimension of 'insufficient competence' on the stress scale. Only 3.6\% of the behaviors of 'in general' on the empowerment scale can be explained by the 'insufficient competence' behavior. There is a 'very low' level of correlation between the behavior of 'in general' on the empowerment scale and the behavior of 'in general' on the perceived stress scale. Only $0.5 \%$ of the behaviors of 'in general' on the empowerment scale can be explained by the behaviors of 'in general' on the perceived stress scale. Therefore, it can be inferred that the behavior of 'in general' is mostly influenced by the behavior of 'insufficient competence' at a rate of $3.6 \%$.

There is a 'high' level of correlation between the behavior of 'insufficient competence' on the stress scale and the behavior of 'in general' on the same scale. $50.9 \%$ of the behaviors of 'insufficient competence' on the stress scale can be explained by the behavior of 'in general' on the same scale.

There is a 'moderate' level of correlation between the behavior of 'disorder' and the behavior of 'in general' on the perceived stress scale. $35 \%$ of the behaviors of 'disorder' can be explained by the behavior of 'in general' on the perceived stress scale.

Finally, we would like to mention about the answers given to the question of "Given that teachers' perception of 'impact' predicts their perception of 'insufficient competence', can someone claim that the variables of age, seniority, gender, and marital status also predict a significant relationship?" As it can be seen on Table 10; gender, age, seniority, and marital status variables have been made control variables in Step 1 to determine the level of correlation between the behaviors of 'impact' and 'insufficient competence'. Then, it has been found in Step 2 that the behavior of 'impact' in teachers significantly predicts the function of the organizational structure. This equation tells that one unit of increase in 'impact' behavior causes 0.171 unit of increase in 'insufficient competence' behavior at an organizational level. As for the variance provided, it can be seen that $4.9 \%$ of 'insufficient competence' behaviors can be explained by 'impact' behavior.

\section{Limitations of the study}

The limitation of this study is to find out if there is a correlation and what kind of a correlation there is between how primary, secondary, and high school teachers perceive psychological empowerment provided for them and their perception of stress.

\section{Recommendations}

- In service trainings can be given to improve the teachers' perception of psychological empowerment during their carriers.

- Simillar studies can be conducted to private schools and the results can be compared with this study.

- Studies for bringing into open the reasons for the stress of teachers can be done.

- What kinds of psychological empowerment studies should be done for the teachers to improve their perception of psychological empowerment during their carriers can also be done. 


\section{References}

Akbağ, M. (2000). Stresle Başa Çıkma Tarzlarının Üniversite Öğrencilerinde Olumsuz Otomatik Düşünceler Transaksiyonel Analiz Ego Durumları ve Bazı Değişkenler Açısından Incelenmesi. Yayımlanmamış Doktora Tezi, Marmara Üniversitesi, İstanbul.

Aslan, M. (1995). Öğretmenlerin Örgütsel Stres Kaynakları. Yayın lanmamış Doktora Tezi, İnönü Üniversitesi, Malatya.

Brown, G. H. (1947). A comparison of sampling methods. Journal of Marketing, 6, 331-337. https://doi.org/10.1177/002224294701100401

Çalışkan, M. (2006). Örgüt Kültürünün Personel Güçlendirmeye Etkisive Bir Uygulama, Yayımlanmamış Yüksek Lisans Tezi, Marmara Üniversitesi Sosyal Bilimler Enstitüsü.

Cardinell, C. (1980). Teacher burn out: An analysis. Action in Teacher Education, 2, 9-10. https://doi.org/10.1080/01626620.1980.10519025

Çavuş, M. F. (2006). Işsletmelerde Personel Güçlendirme Uygulamalarının Örgütsel Yaratıcılık ve Yenilikçiliğe Etkileri Üzerine Imalat Sanayiinde Bir Uygulama, Yayımlanmamış Doktora Tezi, Selçuk Üniversitesi Sosyal Bilimler Enstitüsü.

Chan, D. W., \& Hui, E. K. P. (1995). Burnout and coping among Chinese secondary school teachers in Hong Kong. British Journal of Educational Psychology, 65, 15-25. https://doi.org/10.1111/j.2044-8279.1995.tb01128.x

Conger, J. A., \& Kanungo, R. N. (1988). The Empowerment Process: Integrating Theory and Practice. Academy of Management Review, 13(3), 471-482. https://doi.org/10.5465/amr.1988.4306983

Doğan, S. (2006). Personel Güçlendirme: Rekabette Başarının Anahtarı, KareYayınları, 2. Baskı, İstanbul, 230s.

Doğan, S., \& Demiral, Ö. (2009). Örgütsel Bağlılığın Sağlanmasında Personel Güçlendirme ve Psikolojik Sözleşmenin Etkisine İlişkin Bir Araştırma, Erciyes Üniversitesi Íktisadi ve İdari Bilimler Fakültesi Dergisi, Sayl: 32, ss.47-80.

Emet, C. (2006). Personel Güçlendirme Algıları İle Örgütsel Kültür Arasındaki İlişkinin Bankacıllk Sektöründe Ampirik Olarak Incelenmesi, Yayımlanmamış Yüksek Lisans Tezi, Dumlupınar Üniversitesi Sosyal Bilimler Enstitüsü.

Eskin, M., Harlak, H., Demirkıran, F., \& Dereboy, Ç. (2013). Algılanan Stres Ölçeğinin Türkçeye Uyarlanması: Güvenirlik ve Geçerlik Analizi, New Symposium Journal, Ekim 2013, Cilt 51, Say:3.

Gümüşlüoğlu, L., \& Karakitapoğlu-Aygün, Z. (2009). Bilgi İşçilerinin Örgüte, Lidere Ve İşe Bağlılıklarını Etkileyen Faktörler, 17. Ulusal Yönetim ve Organizasyon Kongresi, 21-23 Mayıs, Osmangazi Üniversitesi, Eskişehir.

Gupta, N. (1981). Some Sources And Remedies of Work Stress Among Teachers, 2-11. National Institute of Education. (ERIC Document Reproduction Service No. ED21496).

Hançer, M., \& George, R. T. (2003). Psychological empowerment of nonsupervisory employees working in full-service restaurants. Hospitallity Management, 22, 3-16. https://doi.org/10.1016/S0278-4319(02)00032-4

Kalaycı, Ş. (2006). Spss Uygulamalı Çok Değişkenli Istatistik Teknikleri (Vol. 2). Asil Yayın Dağıtım.

Kanungo, R. N. (1992). Alienationand Empowerment: Some Ethical Imperatives in Business, Journal of Business Ethics, 11, 1992. https://doi.org/10.1007/BF00870553

Kılıççı, Y. (2000). Okulda Ruh Să̆ğğ . Ankara: Anı Yayıncılık.

Koç, R. (2008). Personel Güçlendirme İle Çalışanların Örgüte Bağlılı̆̆l Arasındaki İlişkiye Yönelik Bir Uygulama, Yayımlanmamış Yüksek Lisans Tezi,Yıldız Teknik Üniversitesi Sosyal Bilimler Enstitüsü.

Koçel, T. (2003). İşletme Yöneticiliği, Genişletilmiş, 9. Baskı, Beta Yayınları, Yayın No: 1382, İstanbul.

Kossack, S., \& Woods, S. (1980). Teacher burnout: Diagnosis, prevention, remediation. Action in Teacher Education, 2 , 34. https://doi.org/10.1080/01626620.1980.10519028

Kyriacou, C. (2001). Teacher stress: Directions for future research. Educational Review, 53, 27-35. https://doi.org/10.1080/00131910120033628

Lin, T. C., Liang, J., \& Tsai, C. C. (2015). Conceptions of memorizing and understanding in learning, and self-efficacy held by university biology majors. International Journal of Science Education, 37(3), 446-468. https://doi.org/10.1080/09500693.2014.992057

Manabete, D. S. S., John, C. A., Makinde, A. A., \& Duwa, S. T. (2016). Job Stress among School Administrators' and Teachers in Nigerian Secondary Schools and Technical Colleges. International Journal of Education, Learning and Development, 4(2), 9-24. 
Maples, M. (1980). Stress: In Defense of Its Positive Dimensions. Action in Teacher Education, 2, 24-26. https://doi.org/10.1080/01626620.1980.10519027

Özbek, A. (2008). İşgören Güçlendirme ve Örgütsel Bağlllık Arasındaki İlişkinin Isşletme İçi Birimler ve Demografik Faktörler Açısından Analizi, Yayımlanmamış Yüksek Lisans Tezi, Gazi Üniversitesi Sosyal Bilimler Enstitüsü, 2008.

Özgen, H., \& Azmi, Y. (2010). Insan Kaynakları Yönetimi: Stratejik Bir Yaklaşım, Nobel Yayın Dağıtım. ISBN: 978-605-397-070-5, 2010.

Parrav, W., Kumar, S., \& Awasthi, P. (2016). Stress among Teachers: A Theoretical Examination, International Journal of Indian Psychology, 3(4), 57.

Pehlivan, A. İ. (2002). Işs Yaşamında Stres. Ankara: Pegem A Yayıncılık.

Seçgin, Y. (2007). Otel İşletmelerinde Personel Güçlendirme Yönetimi ve Bir Uygulama, Yayımlanmamış Yüksek Lisans Tezi, Gaziosmanpaşa Üniversitesi Sosyal Bilimler Enstitüsü, 2007.

Şenel, Ö. (2006). Personel Güçlendirmenin Örgüt Kültürüne Etkisi, Yayımlanmamış Yüksek Lisans Tezi, Dokuz Eylül Üniversitesi Sosyal Bilimler Enstitüsü, 2006.

Siegall, M., \& Gardner, S. (2000). Contextual Factors of Psychological Empowerment. Personel Review, 29(6), 703-722. https://doi.org/10.1108/00483480010296474

Şimşek S. (2006). Örgütlerde Personel Güçlendirme ve Emniyet Örgütünde Personel Güçlendirme Yaklaşımının Belirlenmesine Yönelik Önerileri. www.egm.gov.tr/apk/dergi/42/makale/Savas_SIMSEK.htm E.T. 21.08.2010

Sönmez, A. (2007). Örgütlerde Çalışanları Güçlendirmeye Yönelik Uygulamaların Rekabet Gücüne Etkisi: Bucak/ Burdur Bölgesi $3 S$ Plazala Örneği, Yayınlanmamış Yüksek Lisans Tezi, Dumlupınar Üniversitesi Sosyal Bilimler Enstitüsü.

Spreitzer, G. M. (1995). Psychology empowerment in the work place: dimensions, measurement and validation, Academy of Management Journal, 38(5), 1442-1465. https://doi.org/10.5465/256865

Ünal, S., \& Ümmet, D. (2005). Örgütsel Stres Kaynakları ve Öğretmenlerin Başetme Stratejileri. 14. Ulusal Ĕ̆itim Bilimleri Kongresi., 1. Denizli: Pamukkale Üniversitesi Yayınları.

VanVeldhoven, M. (1996). Psychosociale arbeidsbelasting en werkstress [Psycho-social workpressure and workstress], (Doctoral thesis). Rijksuniversiteit Groningen, Groningen, Netherlands.

Wendt, J. (1980). Coping skills: A goal of Professional preparation, 10. (ERIC Document Reproduction Service No. ED212604).

Wiley, C. (2000). A synthesis of research on the causes, effects, and reduction strategies of teacher stress. Journal of Instructional Psychology, 27(2), 80-87.

Zencir, E. (2004). Bir Liderlik Modeli Olarak Personel Güçlendirme: Ankara'da Bulunan Dört ve Beş Ylldızlı Konaklama İşletmelerinde Bir Araştırma, Yayınlanmamış Yüksek Lisans Tezi, Anadolu Üniversitesi Sosyal Bilimler Enstitüsü.

Zikmund, W. G. (2002). Business research methods, Dryden, Thomson Learning.

\section{Copyrights}

Copyright for this article is retained by the author(s), with first publication rights granted to the journal.

This is an open-access article distributed under the terms and conditions of the Creative Commons Attribution license which permits unrestricted use, distribution, and reproduction in any medium, provided the original work is properly cited. 